\title{
ANISH STRAITS VERSUS TURKISH STRAITS: THE POTENTIAL IMPACT OF PROSPECTIVE RUSSIAN OIL EXPORTS
}

\section{Mehmet Efe Biresselioglu}

Izmir University of Economics, E-mail: efe.biresselioglu@ieu.edu.tr

\section{Muhittin Hakan Demir}

Izmir University of Economics, E-mail: muhittin.demir@ieu.edu.tr

\section{Sinem Dönmez}

Izmir University of Economics, E-mail: sinem.donmez@ieu.edu.tr

\section{Acknowledgements}

This paper is based on the presentation made at the Fifth international conference on Baltic and Nordic Studies in Romania A piece of culture, a culture of peace, re-imaging European communities in the North Sea, Baltic Sea and Black Sea regions, hosted by Valahia University of Târgovişte and the Romanian Association for Baltic and Nordic Studies, August 17-19, 2014. Supported by EEA Grants, contract no 4/22.07.2014.

\begin{abstract}
:
The Danish Straits, which connect Baltic Sea to North Sea as an oil transit choke point, are becoming vastly important as a gateway to Europe for Russian oil exports. In terms of the future source of Russian oil, the country is estimated to hold half of the total Arctic resources. This indicates the forthcoming increase in the importance of Danish Straits in the global energy security. Besides, two additional alternative and important choke points are located in Turkey, which are the Straits of Bosporus and Dardanelles, known as Turkish Straits. These straits are also one of the significant exit points of Russian oil exports but as Russia shifted its direction of oil exports toward Baltic ports, the strategic position of Turkish Straits have been affected from this transition as well. It is an open question whether the Turkish Straits will continue to be the outlet of Russian oil exports or the Danish Straits will take over that position in line with the oil resources development in the Arctic Region. This study aims to analyse the Turkish and Danish Straits and establish their significance in terms of energy security. The current and future oil export strategies of Russia on the existing chokepoints are also discussed, with special emphasis on the potential impacts of Arctic development as Russia continues with the exploration and extraction of Arctic oil resources.
\end{abstract}




\section{Rezumat:}

Strâmtorile daneze, care leagă Marea Baltică de Marea Nordului ca un punct de tranzit petrolier, devin extrem de importante ca poartă de intrare în Europa a exporturilor rusești de petrol. In ceea ce privește sursele viitoare de petrol rusesc, se estimează că țara deține jumătate din resursele arctice totale. Aceasta indică creșterea viitoare a importanței strâmtorilor daneze $\hat{\imath}$ ceea ce privește securitatea energetică globală. În plus, două puncte nodale alternative importante sunt amplasate în Turcia, fiind vorba de strâmtorile Bosfor și Dardanele. Aceste strâmtori reprezintă, de asemenea, debușee importante pentru exporturile rusești de petrol, dar cum Rusia a schimbat direcția exporturilor sale de petrol către porturile baltice, poziția strategică a strâmtorilor turcești a fost și ea afectată. Rămâne deschisă intrebarea dacă strâmtorile turcești vor continua să fie o cale de ieșire a exporturilor rusești de petrol sau strâmtorile daneze vor prelua această poziție ca o consecință a evoluției resurselor de petrol din regiunea arctică. Studiul de față dorește să analizeze strâmtorile turcești și daneze și să stabilească semnificația acestora în termeni de securitate energetică. Strategiile actuale și viitoare de export de petrol ale Rusiei prin punctele de tranzit existente sunt discutate, de asemenea, o atenție sporită fiind acordată impactului potențial al evoluțiilor arctice, de vreme ce Rusia continuă explorarea și extracția resurselor de petrol arctice.

Keywords: Energy security, chokepoints, Turkish Straits, Danish Straits, Russia, Arctic Region, oil

\section{Introduction}

This article aims to analyse the Turkish Straits (Bosporus and Dardanelles) and Danish Straits (Little Belt, Great Belt and The Sound), and establish their significance in terms of energy security. The current and future oil export strategies of Russia on the existing chokepoints are also discussed, with special emphasis on the potential impacts of Arctic development as Russia continues with the exploration and extraction of Arctic oil resources. As the definition of chokepoints refers to the narrow international waterways which hold an importance to a number of states that are suitable of being closed off to commercial and military shipping1, the Turkish and Danish Straits play an important role for Russia in carrying out its energy trade towards the world energy markets. Therefore, this study aims to highlight the importance of the two important chokepoints. In doing so, it reveals the significance of the chokepoints from the perspective of energy security. Since the Turkish and Danish Straits also play an important role in the future of the Russian Arctic development, pointers to Russia's position and strategies on the region are also provided.

In what follows, a discussion on the concept of energy security is provided and the link between the straits and energy security is explained. Next, an analysis of the Turkish and Danish Straits is provided, along with comparison from several

1 Alexander, Lewis M. "The Role of Chokepoints in the Ocean Context." GeoJournal 26, no. 4 (April 1992): 503-509. 
aspects. This analysis also aims to materialize the aforementioned significance of Turkish and Danish Straits concerning energy security and pinpoint the reciprocal relationship between Russia's current and future strategies on its oil exports and the Straits. The next section is devoted to the analysis of two aspects of this relationship, namely, the current influence of Russia on the Turkish and Danish Straits, and the potential impacts of future trends in Russian oil exports, especially the Arctic region strategies, on the Straits. The paper ends with concluding remarks.

\section{The concept of energy security and the role of chokepoints}

The literature on energy security studies reveals that there is no common precise definition of the energy security concept. Energy security has diverse meanings to anyone at particular times in the past leading to a variety of definitions ${ }^{2}$. Main components of energy security are outlined with the perceptions of uninterrupted access to energy sources, utilizing a variety of different sources of energy, not relying on a certain geographic region for energy sources, self-sufficiency in energy and to be protected against external shocks ${ }^{3}$. International Energy Agency (IEA) suggests a concise definition and refers to an "uninterrupted availability of energy sources at an affordable price" 4 . In order to expand the IEA's definition and to cover energy security concerns associated with energy supply pricing, reliability, and adequacy, terms such as rising energy requirements, environmental effects of fossil fuels, global geopolitics, complex trade-offs approach and trade and capital flows are often used in official definitions. ${ }^{5}$

Energy security was primarily conceptualized as a response to the two oil crises during the 1970s. Energy security was initially described as "a condition in which a country perceives a high probability that it will have adequate energy supplies at affordable prices" 6 . Accordingly, the concept was more limited to security of supply by perceiving it as the ability to have adequate supply comparative to demand. Thus, energy security could be detached from the targets associated to economic efficiency and sustainability? ${ }^{7}$. However, the definition of energy security

\footnotetext{
2 Kruyt, Bert, D.P. van Vuuren, and H.J.M de Vries. "Indicators for energy security." Energy Policy, 2009: 2166-2181.

3 Chester, Lynne. "Conceptualising energy security and making explicit its polysemic nature." Energy Policy, 2010: 887-895.

4International Energy Agency. "Energy security".

http://www.iea.org/topics/energysecurity/(accessed 09 20, 2014).

5 Verrasto, Frank and Sarah Ladislaw. Providing Energy Security in an Interdependent World. The Washington Quarterly 30, no 4 (2007): 95-104.

6 Deese, David A. "Energy: Economics, Politics, and Security". International Security 4, no.3 (Winter 1979-1980)

7 Månsson, Andre, Bengt Johansson, and Lars J. Nilsson. "Assessing energy security: An overview of commonly used methodologies." Energy, 2014: 1-14
} 
also implies 'the absence of, protection from or adaptability to threats that are caused by or have an impact on the energy supply chain's. Hence, through the supply chain perspective, energy security can be classified in the main objectives of establishing energy policies that are parallel with economic efficiency and environmental precautions 9 . Consequently as of $21^{\text {st }}$ century, energy security and the military nexus have focused mostly on the protection of international oil tanker choke points and the free movement of oil through these trade routes ${ }^{10}$. It follows that the oil transit chokepoints now characterize significant boundaries of the energy security concept.

The US Energy Information Administration identifies the world's oil transit chokepoints (Figure 1) as Bab-el Mandeb, connecting the Red Sea to the Arabian Sea; Turkish Straits, connecting the Black Sea to the Mediterranean Sea; Danish Straits, connecting the Baltic Sea to the Atlantic Ocean; Strait of Hormuz, located in the entrance of the Persian Gulf; Panama Canal, connecting the Pacific Ocean to the Caribbean Sea and Atlantic Ocean; Suez Canal and SUMED (Suez-Mediterranean) Pipeline, connecting the Red Sea to the Mediterranean Sea and Strait of Malacca, connecting the Indian Ocean to the Pacific Ocean ${ }^{11}$.

\section{Figure 1: World Oil Transit Chokepoints and Estimates of crude oil transit (millions of bpd)}

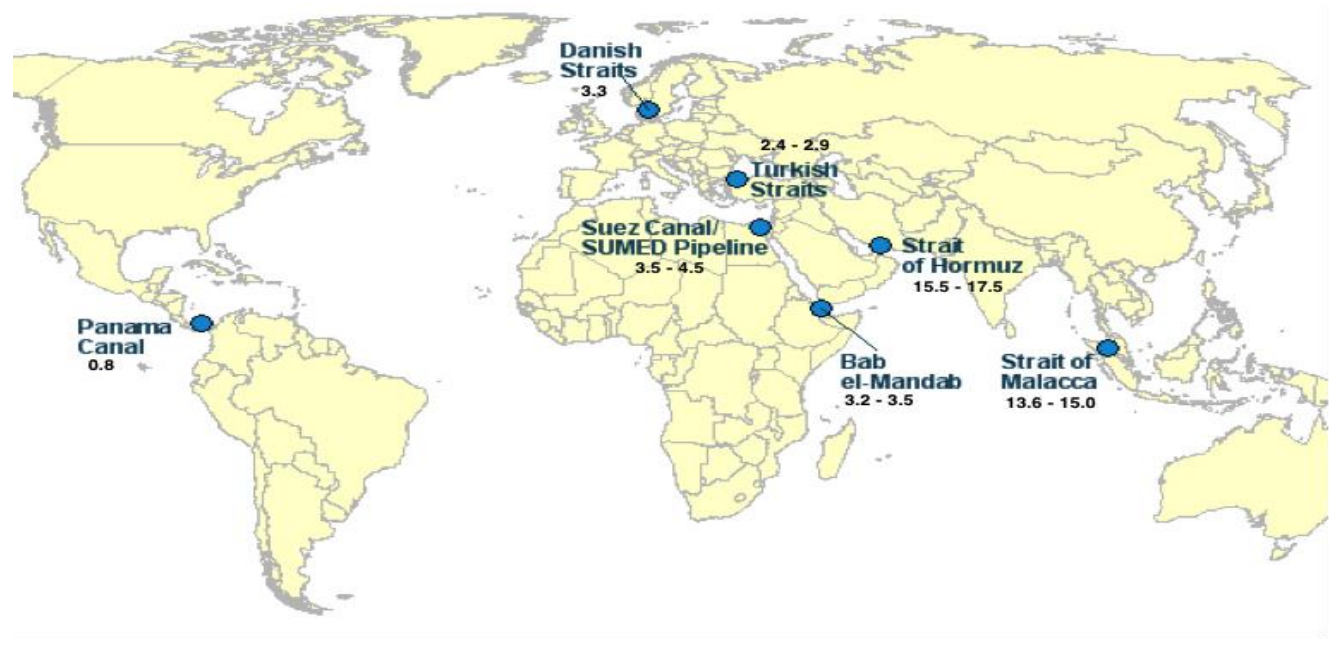

Source: US Energy Information Administration; Emmerson and Stevens 2012 (Various estimates by the authors; EIA)

\footnotetext{
8 Winzer, Christian. "Conceptualizing energy security." Energy Policy, 2012: 36-48.

${ }^{9}$ Kiriyama, Eriko, and Yuya Kajikawa. "A multilayered analysis of energy security research and the energy supply process." Applied Energy, 2014: 415-423.

10 Nuttall, William J., and Manz, Devon L. "A new energy security paradigm for the twenty-first century". Technological Forecasting and Social Change 75, (2008): 1247-1259.

11 US Energy Information Administration. Arctic oil and natural gas resources. 01 20, 2012. http://www.eia.gov/todayinenergy/detail.cfm?id=4650 (accessed 09 24, 2014).
} 
Chokepoints are critical in terms of providing the security of supply since any constraint of passage (a disaster or the oil transportation obstructions) that take place around oil chokepoints may cause supply disruptions, which would result in risks for the energy security of the states involved ${ }^{12}$. The vast amount of crude oil transit through the world's oil transit chokepoints further demonstrates the significance of these chokepoints for the global oil trade. Therefore, threat of sea piracy, terrorist violation, political turmoil and shipping incidents potentially have major adverse impacts on the energy security in terms of supply disruptions and energy price volatility.

\section{An Analysis of Danish Straits and Turkish Straits}

Figure 2 demonstrates that on a high-traffic day, density of cargo vessels passing through the Danish Straits is as high as the density of tankers passing through all the straits on an average-traffic day. Since Danish Straits are the only outlets of some Baltic countries Poland, Latvia, Lithuania and Estonia to the Atlantic Ocean, they are critical chokepoints in the context of the oil transit passage.

\section{Figure 2: Tanker Traffic in Danish Straits}

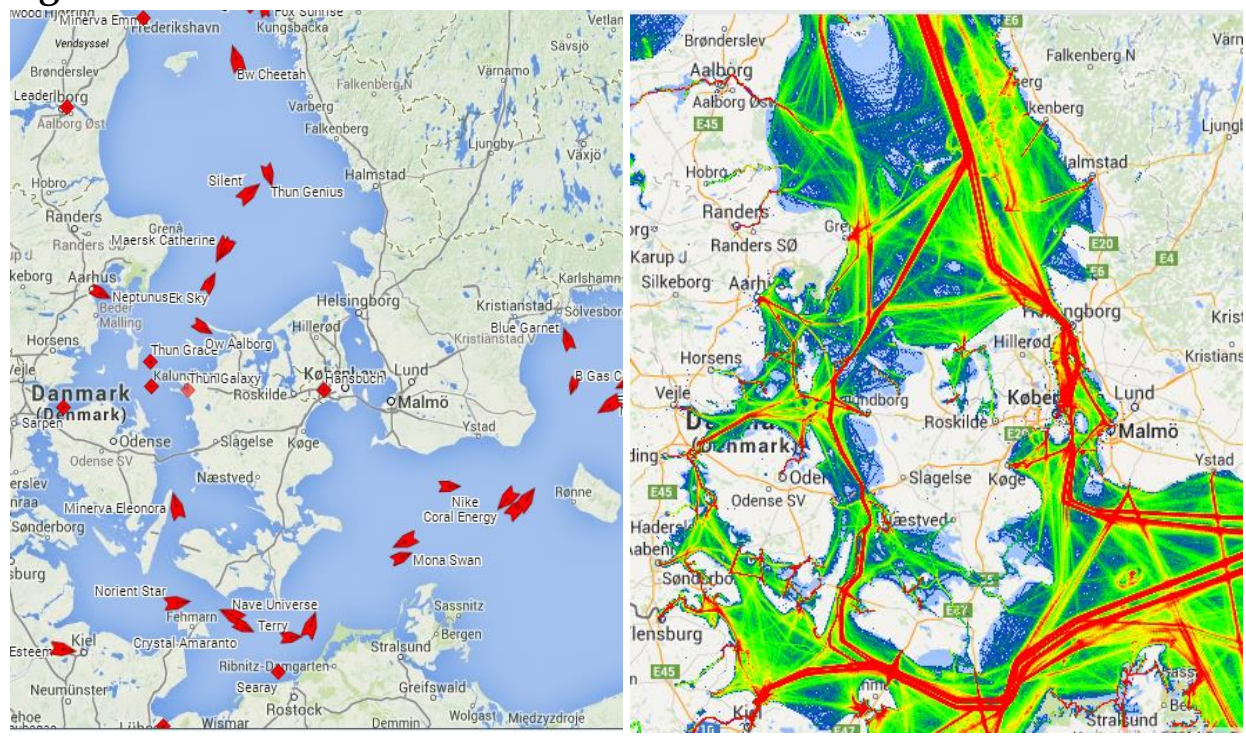

Tankers Cargo Vessels

Source: Marine Traffic, 2014

On the other hand, the traffic density of cargo vessels and tankers through the Turkish Straits Bosporus and Dardanelles is depicted in Figure 3. The passage of 
tankers through the Bosporus Strait has a much higher traffic density relative to the passage through Dardanelles Strait. In 2013, around 23.000 vessels that have the Black Sea ports as origin points passed through the Bosporus. Around 3.000 of these were oil tankers ranking only the third after general cargo and bulk carrier ships. Similarly, around 3.000 tankers passing through the Bosporus Strait in 2013 had Black Sea Ports as destination points, totalling around some 6.000 oil tankers passing to and from Black Sea ports through the Bosporus Strait ${ }^{13}$.

\section{Figure 3: Density of Vessel Traffic in Turkish Straits}



Tankers Cargo Vessels

Source: Marine Traffic, 2014

Figure 4 demonstrates the Turkish Straits, which consists of the Strait of Dardanelles, the Sea of Marmara and the Bosporus. The articulation of the Straits as "Turkish" Straits holds historical, political and legal justification, which comprises of sovereign and jurisdiction rights of Turkey. These rights originate from the principles of international and rely on "Third United Nations Conference on the Standardisation of Geographical Names" that authorizes Turkey with the use of Turkish Straits ${ }^{14}$. These straits are highly important due to their geographical position that provides the sole passage between the Mediterranean and the Black Sea. This geographical position has as well created conflicts between Turkey and the coastal and non-coastal countries of the Black Sea regarding political, economic

13 Bosphorus Strait News. Yearly ship statistics of Bosphorus strait - 2013. 03 13, 2014. http://www.bosphorusstrait.com/2014/03/13/yearly-ship-statistics-of-bosphorus-strait-2013/ (accessed 09 24, 2014).

14 İnan, Yüksel. "The Current Regime of the Turkish Straits." Perceptions Journal of International Affairs 6, no. 1 (March-May 2001). 
and strategic welfares ${ }^{15}$. Having one of the highest traffic volumes among waterways of the world, the Bosporus also plays an important economic role. This is also true regarding local people who deal with fishing activities, boats services and car ferry businesses. During the Ottoman Era, the Bosporus and Dardanelles Straits also had a strategic role in terms of domestic economy, as well as to provide economic and military advantage over Russia ${ }^{16}$.

\section{Figure 4: The Turkish Straits - Bosporus and Dardanelles}

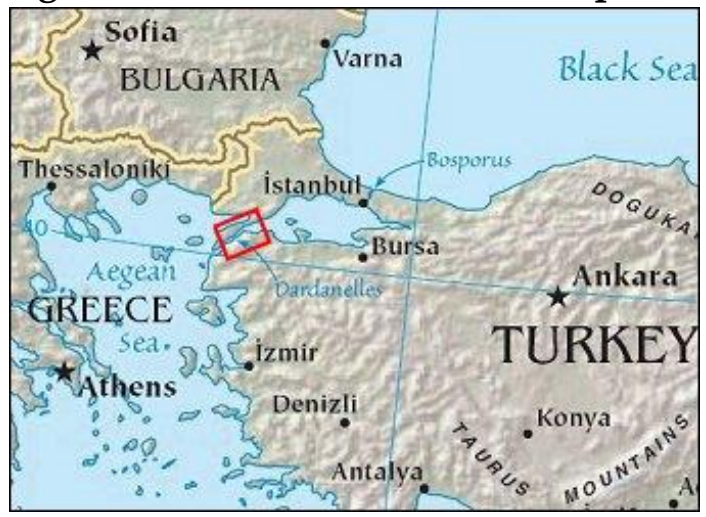

Source: Energy Information Administration (EIA)

The Straits have been regarded as the internal waters of the Ottoman Empire, and the countries have been given free passage rights by bilateral agreements ${ }^{17}$. The 1936 Montreux Convention has recognized the international status of the Turkish Straits and assures the international freedom of passage of the commercial vessels during peacetime. However the convention also gives Turkey the right to close the Straits to the passage of warships in wartime and to merchant ships of the enemy nations. Moreover, the transit passage of large vessels and tankers are restricted to daylight hours.

From the energy and logistics perspectives, Turkish Straits, one of the global oil transit chokepoints, play an important role for the security of oil supply chains, hence energy security. Due to the increased volume of oil exports from the Caspian Sea region implying a vast amount of increase in the vessel traffic in the narrow passages of the straits, fears related to the navigational safety and environmental

\footnotetext{
15 Pıçak, Murat. "Political, Economic and Strategic Dimension of the Turkish-Soviet Straits Question Emerged After World War II." International Journal of Business and Social Science 2, no. 15 (2011): 173189.

16 Oral, Nilüfer and Öztürk, Bayram. The Turkish Straits, maritime safety, legal and environmental aspects. Turkish Marine Research Foundation, Istanbul: Publication Number 25. 2006.

17 Aybay, Gündüz, and Nilüfer Oral. "Turkey's Authority to Regulate Passage of Vessels Through the Turkish Straits." Perceptions Journal of International Affairs 3, no. 2 (June-August 1998).
} 
risks to the Straits have been upraised ${ }^{18}$. Currently the Turkish Straits are among the most significant and the most dangerous oil chokepoints. Two major accidents in the straits have resulted in significant spills over the sea as well as long-term adverse effects on the environment. The first such accident is the 1979 collision between the Romanian ship Indipendenta and the Greek tanker Evriali that resulted in the death of 43 crew and oil spill of 70 thousand tonnes. The other accident was the 1994 fire on board of the Greek ship Nassia as it was passed through the Bosporus Strait, and caused the death of 27 people and the spillage of 20 thousand tonnes of oil ${ }^{19}$.

The concerns rose as a result of accidents, risks and threats to human life, the environment and energy security have brought up projects that aim to bypass Bosporus and the Dardanelles. The main bypass projects are: The BurgasAlexandrupolis Project, The Constanta-Trieste project (PEOP, the Pan-European Oil Pipeline) and The Samsun-Ceyhan Pipeline Project (TAPCO).

The Burgas-Alexandroupolis Project (Figure 5) aims transport oil from Bulgarian Black Sea port of Burgas to Greek Port of Alexandroupoli. The project which was initiated after an agreement signed by Russia, Greece and Bulgaria, however, it has later been opposed by Bulgarian government due to environmental concerns.

\section{Figure 5: The Burgas-Alexandroupolis Project}

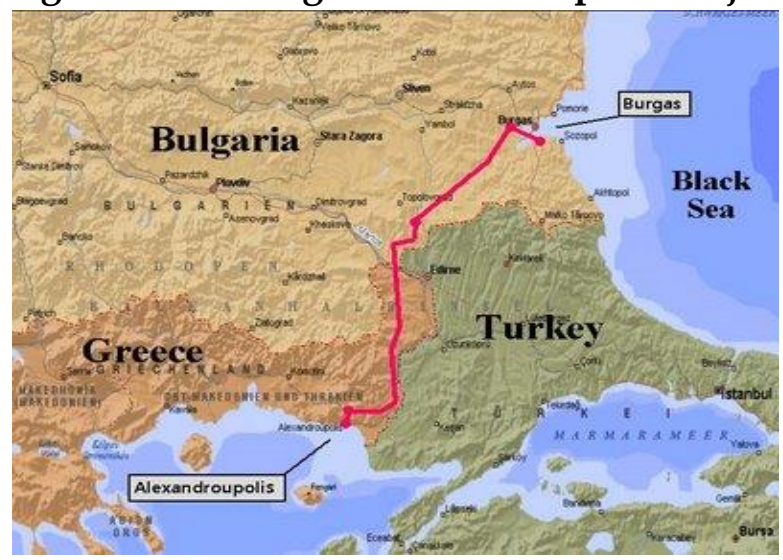

Source: Neftegaz

The Constanta-Trieste project (Figure 6) also known as the Pan-European Pipeline, to start from Constanta in Romania and pass through Serbia, Croatia and Slovenia, and end at Trieste, Italy, is the most expensive bypass project. As of 2014, the project has been in uncertainty with no sign of onward action.

18 US Energy Information Administration. Arctic oil and natural gas resources. 01 20, 2012. http://www.eia.gov/todayinenergy/detail.cfm?id=4650 (accessed 09 24, 2014)

19 Roberts, John. Pipeline Politics: Maritime motorway fuel environmental concerns. 10 16, 2012. http://www.ft.com/intl/cms/s/0/d67773d8-114d-11e2-8d5f-00144feabdc0.html\#axzz3E92giLD3 (accessed 09 23, 2014). 


\section{Figure 6: The Constanta-Trieste project}

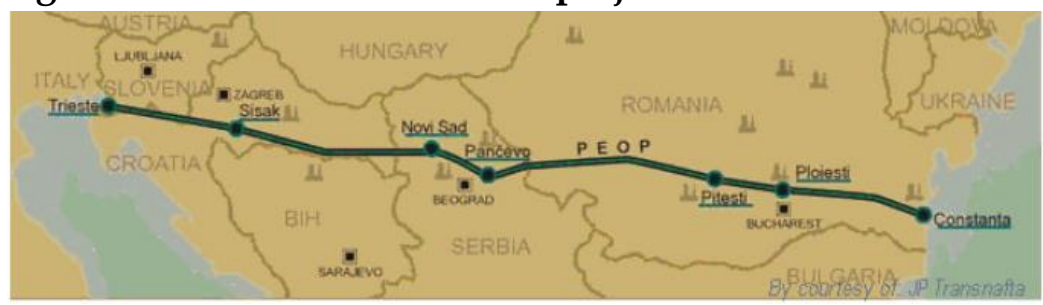

Source: Transnafta

The last project to bypass the Turkish Straits is the Samsun-Ceyhan Pipeline Project (Figure 7), to be constructed wholly within Turkish borders, also involves a new sea port in Samsun. However, currently, this project is not realized either ${ }^{20}$.

\section{Figure 7: Samsun-Ceyhan Pipeline Project}

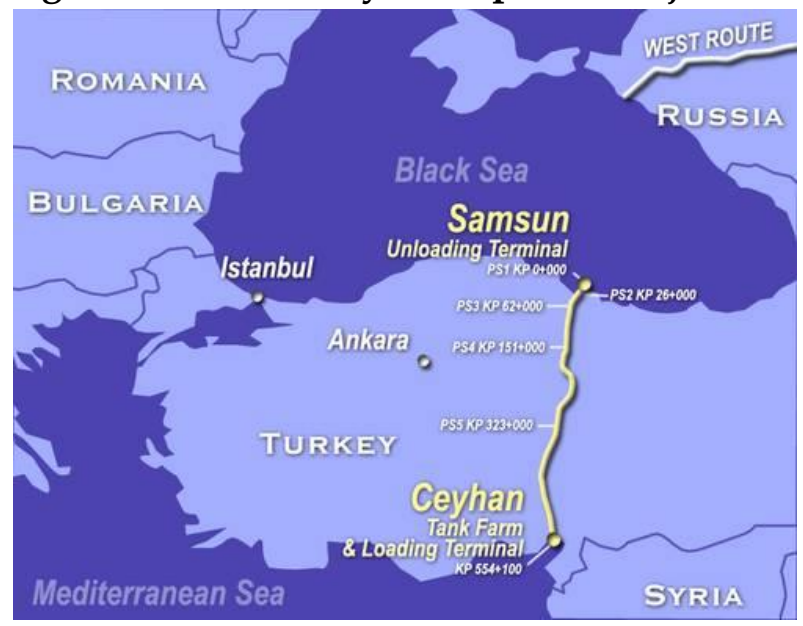

Source: Eurasia Daily Monitor, Jamestown Foundation, 2009

The Danish Straits, on the other hand, are the essential connection points between the Baltic Sea and the oceans of the world. The Straits consist of the Sound, the Great Belts and the Little Belt (Figure 8). The Sound offers the most straight access route to the Baltic Sea. The Great Belt is the least difficult strait in terms of navigation, however, weather and climate conditions may occasionally create problems as well. The least important Danish Strait in terms of international navigation is the Little Belt, due to navigational difficulties caused by heavy currents and shoals ${ }^{21}$.

20 Sagers, Matthew J., John C. Webb, and Laurent Ruseckas. New Realities in Oil Transit Through the Turkish Straits. Special Report, Massachusetts: IHS CERA, 2011.

21 Oude Elferink, Alex G. "The Regime of Passage Through the Danish Straits." The International Journal of Marine and Coastal Law 15, no. 4 (2000): 555-566. 


\section{Figure 8: The Danish Straits - Little Belt, Great Belt and Oresund}

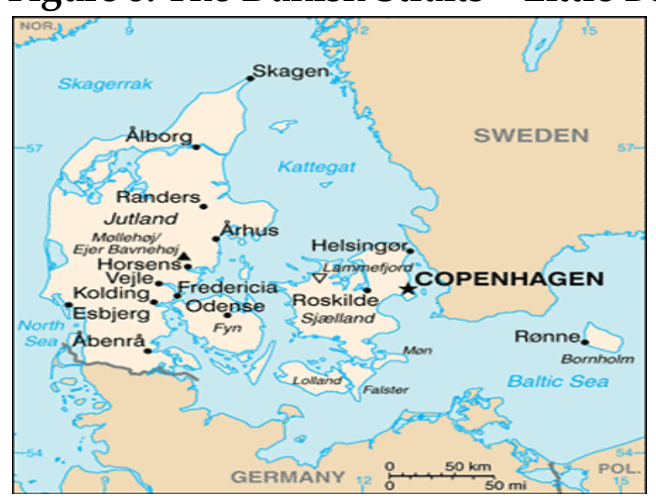

Source: Petroleum World

Similar to the Turkish Straits, the Danish Straits are international waterways, and are is controlled under the 1857 international agreement, Copenhagen Treaty, International Maritime Organization (IMO) regulations, as well as Danish and Swedish national laws. The Danish government collects revenues called as Sound Dues toll from international merchant ships. Navigation through Danish Straits is complex due to currents, strong weather conditions, and geographic conditions. Nevertheless, the passage of large tankers and vessels are not limited to daylight hours as it is the case with the Bosporus ${ }^{22}$. Due to environmental concerns, IMO has entitled the Baltic Sea as a special sea area with a number of limitations for oil, oily water, oily waste discharging and garbage into the sea and for the emissions in the air $^{23}$.

The importance of the Danish Straits has increased together with the reduction of Russia's oil shipments through Turkish Straits and the increasing use of Baltic ports for Russia's oil exports. According to the data provided by EIA, in 2013, an average of 3.3 million barrels per day of oil has been transported through the Danish Straits, $43 \%$ of which originates from Port of Primorsk, whereas only 2.9 million barrels per day of oil has been transported through the Turkish Straits ${ }^{24}$.

It follows that Russia's oil exports and its associated strategies are crucial determinants for Turkish and Danish Straits. These phenomena are discussed next.

\section{Russia's Strategies and Influence on the Turkish and Danish Straits}

To capture the current drivers of Russia's oil exports and their reflections on the Straits, one needs to identify the profile of Russia as an oil exporter. According to

\footnotetext{
22 Sagers, Matthew J., John C. Webb, and Laurent Ruseckas. New Realities in Oil Transit Through the Turkish Straits. Special Report, Massachusetts: IHS CERA, 2011.

${ }^{23}$ Luciani, Giacomo. Restrictions of Passage, Accidents and Oil Transportation Norms: Impact on supply security. Working Document, Brussels: Centre for European Policy Studies, 2011.

24 US Energy Information Administration. Arctic oil and natural gas resources. 01 20, 2012. http:/ / www.eia.gov/todayinenergy/detail.cfm?id=4650 (accessed 09 24, 2014).
} 
EIA (2013), more than $50 \%$ of federal revenues of Russia come from hydrocarbons exports. Russia ranks as the second largest producer of dry natural gas and third largest producer of liquid fuels in the world, with the eight largest reserves of oil and the second largest reserves of natural gas. Russia is one of the world's major exporters of oil and heavily uses the Danish Straits to reach the world markets. Major export destinations of Russia are European countries, having more than 85 per cent of a share. Therefore, Russia relies on transit routes involving Danish Straits for its oil export to Europe.

Russia's recently constructed export terminals are in Primorsk and Ust-Luga in the Gulf of Finland. The Baltic States aim to preserve their position as Russia's transit countries in order to maintain their earnings of transit income. On the other hand, they have also been trying to decrease their dependency on Russia through liberalization, self-reliance, savings on energy and energy efficiency and diversification of sources ${ }^{25}$. The main oil export outlet of Russia in the Baltic region is the Port of Primorsk in the Baltic Sea and the Baltic Pipeline System ${ }^{26}$. However Russia plans to expand the Baltic Pipeline System in order o bypass Belarus and the Baltic States. This will also make it possible to increase the amounts of exports by nearly doubling the capacity of the north western ports of Ust-Luga, Primorsk, Vysotsk, and Kaliningrad (Figure 9) by 201527. This planned increase of exports originating from the Russia's ports in the Baltic Sea will result in a reduced use of Black Sea route of Russia as oil export outlet, thus resulting in a decrease in the use of Turkish Straits for this purpose.

\section{Figure 9: Russian Ports in the Baltic Sea}

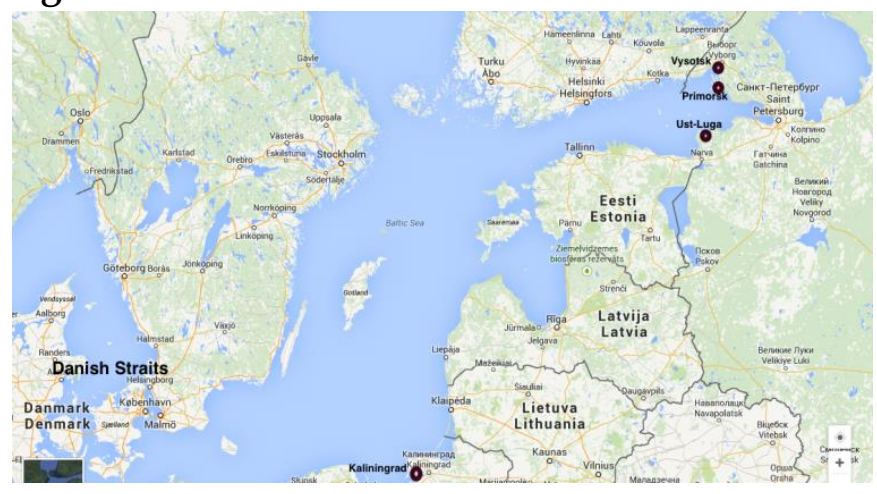

Source: Google Maps

25 Oldberg, Ingmar. Soft Security in the Baltic Sea Region: Russian Interests in the Council of Baltic States. Occasional Papers, Stockholm: Swedish Institute of International Affairs, 2012.

${ }^{26}$ Konon'czuk, Wojciech. Russia's Best Ally: The Situation of the Russian Oil Sector and Forecasts for its Future. OSW Studies, Warsaw: Centre for Eastern Studies, 2012.

27 Grigas, Agnia. Legacies, Coercion and Soft Power: Russian Influence in the Baltic States. Briefing Paper, London: Chatham House, 2012. 
The preceding discussion points to the fact that the direction that Russia is about to take regarding its oil exports is one of the primary factors that will define the future positions of Turkish and Danish Straits. One important development regarding this topic is the Arctic oil resources. The following section discusses this.

\section{Potential impacts of the future trend}

\section{in Russian oil exports on the Danish Straits}

The increase in the volume of oil exports of has in turn led to an increase in the volume of oil shipments through Danish Straits in the recent years. As one of the biggest oil exporters in the world, Russia is most likely to continue with its oil shipments via implementing policies to maintain its leading role in this arena along with the strategy of bypassing other states. Shipments through the Baltic Sea to the international markets constitute a key component of Russia's strategy in this context. At this point, it would be suitable to elaborate on the critical position of the energy resources of the Arctic Region.

\section{Figure 10: Division of Arctic oil resources}

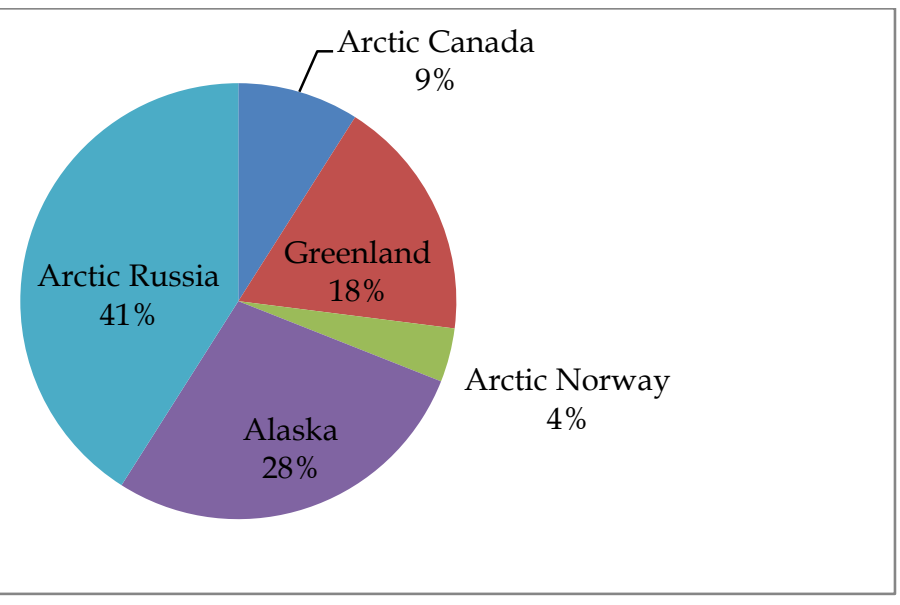

Source: Lindholt and Glomsrød, 2011

The Arctic region is estimated to hold the $13 \%$ of world's undiscovered conventional oil resources, which is approximately 90 billion barrels and $30 \%$ of the natural gas resources, which is nearly $1670 \mathrm{tcf}^{28}$. With the effects of climate change, the accessibility of the untapped resources has now become easier. According to Lindholt and Glomsrød, the highest percentage of the undiscovered Arctic oil resources is estimated to be in Arctic Russia 41\%; followed by Alaska with 28\%, 
Greenland with 18\%, Arctic Canada with 9\%, and Arctic Norway with 4\% ${ }^{29}$, as shown in Figure 10.

Among the five Arctic countries Russia, USA, Norway, Denmark (Greenland) and Canada, Russia holds the highest share of Arctic oil and gas resources, by an estimated 52\%. Russia also has the highest strategic interest in the Arctic. Since the existing oil fields have been matured and the production has been in a shortfall, increasing extraction operations in the Arctic Region is important for Russia ${ }^{30}$. This also constitutes a significant component of Russia's energy security strategy. The fact that Russian North has accounted for 20\% of Russia's Gross Domestic Production (GDP) and 22\% of Russian exports, further justifies this interest ${ }^{31}$. Russian Federation's recently published strategy documents titled "The National Security Strategy of the Russian Federation through 2020" and "The Principles of State Policy of the Russian Federation in the Arctic until 2020 and Beyond" state Russia's desire to guarantee the Russian control and governance over the claimed zones in the Arctic together with the resources located within ${ }^{32}$. Gira divided the Russian energy activity into following three different phases in the Arctic;

“First Phase (2008-2010): Russia's preparation for the legitimization of the external boundaries of its sector in the Arctic,

Second Phase (2011-2015): Legitimization at the international level of the external boundaries of Russia's sector in the Arctic and implementation of Russia's competitive advantage in the sphere of resource extraction and transportation.

Third Phase (2016-2020): During this period the transformation of Russia's sector in the Arctic into the main natural resource base of strategic importance has to be implemented" 33 .

Accordingly, Arctic region is important for Russia future competitiveness on global energy markets. ${ }^{34}$ Exports of Arctic oil resources will provide strategic

29 Lindholt, Lars, and Solveig, Glomsrød. The role of the Arctic in future global petroleum supply. Discussion Paper, Oslo: Statistics Norway, 2011.

${ }^{30}$ Johnston, Peter F. "Arctic Energy Resources: Security and Environmental Implications." Journal of Strategic Security 5, no. 2 (2012): 13-32.

31 Keil, Kathrin. "The Arctic: A new region of conflict? The case of oil and gas." Cooperation and Conflict 49, no. 2 (2013): 162-190.

32 Perry M., Charles, and Andersen Bobby. New Strategic Dynamics in the Arctic Region: Implications for National Security and International Collaboration. Washington DC: The Institute for Foreign Policy Analysis, Inc., 2012.

33 Gira, Vvytautas Sirijos, The significance of the Arctic in Russia's foreign policy: why Arctic policy issues are of topical interest to the Baltic States. Eastern Pulse 1(29). 2010 http://www.eesc.lt/uploads/news/id358/Eastern\%20Pulse\%201\%20(29).pdf $\quad$ (accessed 0707 2015).

34 Zysk, Katarzyna, Russia's Arctic strategy: ambitions and constraints. Features, 2010 http://www.intelros.ru/pdf/JFQ/57/16.pdf (Accessed 26 May 2014). 
advantages for Russia by decreasing the necessity of shipment or piping of products through many transit countries or through busy and risky chokepoints such as the Turkish Straits ${ }^{35}$. Evidently, the Arctic region is of strategic importance for Russia and will continue to be in its priority agenda in the future due to declining reserves of fossil fuels. An equally important concern is the leverage that it provides for Russia because of its dependency on hydrocarbon exports, a key to Russia's national security and economy ${ }^{36}$.

\section{Conclusion}

The straits over different regions of the world have always played a significant role, firstly in terms of their geographical positions. In many cases, straits serve as the connection passages between a number of a country and the other parts of the world. This geographical importance, when coupled with geopolitical, economics, and logistics concerns become even more critical. Common such examples are concerns regarding the limitations and control procedures for using the straits as transit passages, political and economic relationships with the country that controls the straits, delays and blockages resulting from conflicts, perceived risks of conflicts or piracy in the strait region, weather conditions that may favour or prevent passage from a particular strait, the route cost associated with using a strait.

To this end, the discussion on straits turns out to be dynamic and complicated. The concerns on energy security add yet another dimension to the straits phenomenon.

The countries that are suppliers of energy sources need to include the possible use of straits in their design phase and for continuously maintaining of their energy markets. In many cases, this would involve the establishment of the logistics infrastructure including the construction of ports and terminals to be used in energy transport, allocation of port capacities, developing and supporting pipeline projects, and also dynamically assessing the convenience of alternate routes in terms of costs, risks, lead times, for route selection.

The energy security of countries that import energy sources are directly affected by the choice of straits that lie along the energy transportation routes. To begin with, the country that controls the strait used as a passage is most likely to enjoy the benefits of a transit country -with some extra controlling power- for energy. Other countries in the route share these advantages to some extent. Therefore, they favour the transportation on the route that trespasses their country, and support the

35 Johnston, Peter F. "Arctic Energy Resources and Global Energy Security." Journal of Military and Strategic Studies 12, no. 2 (2010): 1-20.

${ }^{36}$ Käpylä, Juha, and Harri Mikkola. The Global Arctic: The Growing Arctic Interests of Russia, China, The United States and The European Union. Briefing Paper, Helsinki: The Finnish Institute of International Affairs, 2013. 
construction and maintenance of the logistics infrastructure on this route. To this end, these countries provide political and financial support. However, these countries may also suffer from the associated transportation and logistics and from political risks. Any problem related with bad weather conditions or conflict between two countries over the route - as in the case with the recent dispute between Russia and Ukraine - may adversely affect the energy security of all countries that are on the transportation route through delays or even shortages of energy. In such case, the flexibility of supplying energy from alternate sources, alternate routes or alternate countries would become crucial for these countries. This situation once more emphasizes the 'diversification' concept of energy security as well as the impacts of risks associated with the use of straits. Hence, this establishes another connection between the straits and energy security.

The development of Russian Arctic oil resources is expected to influence the Russian energy exports and result in an increase in the tanker traffic in the Danish Straits while a decrease of the exports towards the Black Sea outlet, which is the Turkish Straits. Both Danish and Turkish Straits hold an important role for serving as oil transit chokepoints for Russia, however due to the concerns over Turkish Straits and the change in the direction of Russian oil flow, Danish Straits are likely to become an important route for Russia in near future. This will result in an escalation in the importance of the position of Danish Straits' in the global energy security.

\section{References:}

\section{A: Books, articles, published documents:}

Alexander, Lewis M. "The Role of Chokepoints in the Ocean Context." GeoJournal 26, no. 4 (April 1992): 503-509.

Aybay, Gündüz, and Nilüfer Oral. "Turkey's Authority to Regulate Passage of Vessels Through the Turkish Straits." Perceptions Journal of International Affairs 3, no. 2 (June-August 1998).

Chester, Lynne. "Conceptualising energy security and making explicit its polysemic nature ." Energy Policy, 2010: 887-895.

Deese, David A. “Energy: Economics, Politics, and Security". International Security 4, no.3 (Winter 1979-1980).

Oude Elferink, Alex G. "The Regime of Passage Through the Danish Straits." The International Journal of Marine and Coastal Law 15, no. 4 (2000): 555-566.

Emmerson, Charles, and Paul Stevens. Maritime Choke Points and the Global Energy System: Charting a Way Forward. Briefing Paper, London: Chatham House, 2012.

Grigas, Agnia. Legacies, Coercion and Soft Power: Russian Influence in the Baltic States. Briefing Paper, London: Chatham House, 2012. 
İnan, Yüksel. "The Current Regime of the Turkish Straits." Perceptions Journal of International Affairs 6, no. 1 (March-May 2001).

Johnston, Peter F. "Arctic Energy Resources and Global Energy Security." Journal of Military and Strategic Studies 12, no. 2 (2010): 1-20.

Johnston, Peter F. "Arctic Energy Resources: Security and Environmental Implications." Journal of Strategic Security 5, no. 2 (2012): 13-32.

Käpylä, Juha, and Harri Mikkola. The Global Arctic: The Growing Arctic Interests of Russia, China, The United States and The European Union. Briefing Paper, Helsinki: The Finnish Institute of International Affairs, 2013.

Keil, Kathrin. "The Arctic: A new region of conflict? The case of oil and gas." Cooperation and Conflict 49, no. 2 (2013): 162-190.

Kiriyama, Eriko, and Yuya Kajikawa. "A multilayered analysis of energy security research and the energy supply process." Applied Energy, 2014: 415-423.

Kononczuk, Wojciech. Russia's Best Ally: The Situation of the Russian Oil Sector and Forecasts for its Future. OSW Studies, Warsaw: Centre for Eastern Studies, 2012.

Kruyt, Bert, D.P. van Vuuren, and H.J.M de Vries. "Indicators for energy security." Energy Policy, 2009: 2166-2181.

Lindholt, Lars, and Solveig Glomsrød. The role of the Arctic in future global petroleum supply. Discussion Paper, Oslo: Statistics Norway, 2011.

Luciani, Giacomo. Restrictions of Passage, Accidents and Oil Transportation Norms: Impact on supply security. Working Document, Brussels: Centre for European Policy Studies, 2011.

Månsson, Andre, Bengt Johansson, and Lars J. Nilsson. "Assessing energy security: An overview of commonly used methodologies." Energy, 2014: 1-14.

Nuttall, William J., and Manz, Devon L. "A new energy security paradigm for the twenty-first century". Technological Forecasting and Social Change 75, (2008): 1247-1259.

Oldberg, Ingmar. Soft Security in the Baltic Sea Region: Russian Interests in the Council of Baltic States. Occasional Papers, Stockholm: Swedish Institute of International Affairs, 2012.

Oral, Nilüfer and Öztürk, Bayram. The Turkish Straits, maritime safety, legal and environmental aspects. Turkish Marine Research Foundation, Istanbul: Publication Number 25. 2006

Pıçak, Murat. "Political, Economic and Strategic Dimension of the Turkish-Soviet Straits Question Emerged After World War II." International Journal of Business and Social Science 2, no. 15 (2011): 173-189.

Perry M., Charles, and Andersen Bobby. New Strategic Dynamics in the Arctic Region: Implications for National Security and International Collaboration. Washington DC: The Institute for Foreign Policy Analysis, Inc., 2012.

Sagers, Matthew J., John C. Webb, and Laurent Ruseckas. New Realities in Oil Transit Through the Turkish Straits. Special Report, Massachusetts: IHS CERA, 2011.

Verrasto, Frank and Sarah Ladislaw. Providing Energy Security in an Interdependent World. The Washington Quarterly 30, no 4 (2007): 95-104.

Winzer, Christian. "Conceptualizing energy security." Energy Policy, 2012: 36-48. 


\section{B: Web postings:}

Bosphorus Strait News. Yearly ship statistics of Bosphorus strait - 2013. 03 13, 2014. http:/ / www.bosphorusstrait.com/2014/03/13/yearly-ship-statistics-of-bosphorus-strait2013/ (accessed 09 24, 2014).

Gira, Vvytautas Sirijos, The significance of the Arctic in Russia's foreign policy: why Arctic policy issues are of topical interest to the Baltic States. Eastern Pulse 1(29). 2010

http://www.eesc.lt/uploads/news/id358/Eastern\%20Pulse\%201\%20(29).pdf (accessed 07 07 2015).

Google Maps.

https://www.google.com/maps/place/Rusya/@55,103,3z/data=!3m1!4b1!4m2!3m1!1s0x4 53c569a896724fb:0x1409fdf86611f613 (accessed 09 22, 2014).

International Energy Agency. "Energy security".

http://www.iea.org/topics/energysecurity/(accessed 09 20, 2014).

Marine Traffic. http://www.marinetraffic.com/en/?lang=en (accessed 09 20, 2014).

Neftegaz. $\quad$ http://neftegaz.ru/images/Neft\%20Perey/Bulgarian\%20pipeline.jpg (accessed 09 20, 2014)

Petroleum World. http://www.petroleumworld.com/imagesjul2004/danish-straits450.gif (accessed 09 20, 2014).

Roberts, John. Pipeline Politics: Maritime motorway fuel environmental concerns. 10 16, 2012. http:/ / www.ft.com/intl/cms/s/0/d67773d8-114d-11e2-8d5f-

00144feabdc0.html\#axzz3E92giLD3 (accessed 09 23, 2014).

"Russia Country Analysis Brief." US Energy Information Administration. 11 26, 2013. http://www.eia.gov/countries/analysisbriefs/Russia/russia.pdf (accessed 09 24, 2014).

Socor, Vladimir. Russia Shows Interest in Samsun-Ceyhan Oil Pipeline Project. Eurasia Daily Monitor, Vol.6, Issue: 157, Jamestown 2009. http://www.jamestown.org/single/?tx_ttnews\%5Btt_news $\% 5 \mathrm{D}=35415 \# . V N a U h f m s X d c$ (accessed 09 26, 2014)

Transnafta.

https://www.energy-community.org/pls/portal/docs/414188.PDF (accessed 09 24, 2014)

US Energy Information Administration. Arctic oil and natural gas resources. 01 20, 2012. http://www.eia.gov/todayinenergy/detail.cfm?id=4650 (accessed 09 24, 2014).

World Oil Transit Chokepoints. US Energy Information Administration. 10 10, 2012. http://www.eia.gov/countries/analysisbriefs/World_Oil_Transit_Chokepoints/wotc.pdf (accessed 10 10, 2014).

World Oil Transit Chokepoints. US Energy Information Administration. 08 22, 2012. http://www.eia.gov/countries/analysisbriefs/World_Oil_Transit_Chokepoints/images/B osporusDistance.gif (accessed 09 23, 2014)

Zysk, Katarzyna, Russia's Arctic strategy: ambitions and constraints. Features, 2010 http://www.intelros.ru/pdf/JFQ/57/16.pdf (Accessed 26 May 2014). 